\title{
Xinjiang and Sino-Turkish Ties
}

\section{Jérôme Doyon}

Translator. N. Jayaram

\section{OpenEdition \\ Journals}

Electronic version

URL: http://journals.openedition.org/chinaperspectives/5470

DOI: $10.4000 /$ chinaperspectives. 5470

ISSN: 1996-4617

\section{Publisher}

Centre d'étude français sur la Chine contemporaine

\section{Printed version}

Date of publication: 1 January 2011

Number of pages: $75-76$

ISSN: 2070-3449

\section{Electronic reference}

Jérôme Doyon, «Xinjiang and Sino-Turkish Ties », China Perspectives [Online], 2011/1 | 2011, Online since 30 March 2014, connection on 15 September 2020. URL : http://journals.openedition.org/ chinaperspectives $/ 5470$

(C) All rights reserved 


\section{Xinjiang and Sino-Turkish Ties}

\section{Analysis by Jérôme Doyon based on:}

- Zan Tao, (1) "Sino-Turkish relations and Turkey's point of view on China's rise," Alabo shijie yanjiu, no. 4, July 2010.

- Zhu Xiang, (2) "Study of Sino-Turkish relations," Dongfang qiye wenhua, May 2010.

- Deng Hongying, (3) "Analysis of transformations in Turkish diplomacy," Xiandai guoji guanxi, no. 10, November 2010.

- Xie Mengcen, (4) "Analysis of particularities and tendencies of the current East-Turkistan movement," Xue lilun, no. 30, 2009.

- Wei Chaoran, (5) "Analysis of Xinjiang's political stability," Gaodengjiayu yu xueshu yanjiu, no. 7, 2010.

V iolent incidents in Xinjiang appear to the Chinese to be proliferating since 1990, especially after the media focus on the events of July 2009 in Urumqi. Chinese analysts tend to highlight the events' links to the internationalisation of pro-independence activism through the "East Turkistan movement" (东突, Dongtu). This internationalisation theme has a more general bearing on the issue of "three evil forces" (三股势力) ${ }^{(6)}$ deemed to be growing in Xinjiang via transnational pro-East Turkistan organisations whose numbers have been expanding since the advent of economic reforms in China. Xie Mengcen stresses the formation in the United States in 2004 of two organisations that have emerged as beacons of the political independence quest on the global scene: the "World Uyghur Congress" (7) (世界维吾尔代表大会, shijie weiwu'er daibiao dahui) and the "East Turkistan Government in Exile" (8) (东突厥斯坦流讯政府, dongtujuesitan liuwang zhengfu). Most articles on the internationalisation of the East Turkistan movement fail to mention Turkey, although a pan-Turkic ideological basis (泛突厥主义, fan tujue zhuyi) is often attributed to these organisations. On the other hand, Sino-Turkish relations are constantly invoked in discussions of Xinjiang. They stress Turkey's position as one of the main bases of the East-Turkistan movement. They particularly emphasise the need for Ankara's clear political support to China's stand regarding Xinjiang. At the same time, they tend to show that it is through Sino-Turkish collaboration on Xinjiang's stability that Turkey could retain its influence on Central Asia, where China's importance is growing, especially after the creation in 2001 of the Shanghai Cooperation Organisation (SCO), of which Turkey is not a member.
Even after the establishment of diplomatic relations with Turkey in 1971, China has been unable to improve its image among the Turks, as Zan Tao observes. The Korean War, in which the Turkish army fought alongside the Americans, left a negative impression of Chinese Communists in Turkey. Also, Turkish nationalists have bristled at the support to Turkey's extreme leftists from the Chinese Communist Party in the 1960s. Bilateral relations have developed mainly since the 1980s. It is only recently that Turkish elites have taken note of China's rising power, Zan notes. Then again, China has yet to acquire the strategic importance that the United States, the neighbouring European Union countries, Central Asia, or the Middle East enjoy in Turkey's eyes.

Meanwhile, Zan Tao as well as Zhu Xiang point out the eastward shift (向 "东方," xiang "dongfang") in Turkish diplomatic focus since the end of

1. Zan Tao is assistant professor at the history department at Peking University.

2. Zhu Xiang belongs to the Middle-East research centre at Northwest University in Xi'an.

3. Deng Hongying is with the political studies department of the Zhongnan University of Economics and Law at Wuhan.

4. Xie Mengcen is with the Xi'an Institute of Politics.

5. Wei Chaoran is a PhD student at the Institute of politics and Public Administration, Xinjiang University, Urumqi.

6. Expression covering terrorism, separatism, and religious extremism.

7. The Munich-based organisation vows adherence to peaceful means and purports to speak for Uyghurs inside and outside Xinjiang. Since 2006 its president is Rebiya Kadeer.

8. The Washington-based organisation has a "prime minister," Anwar Yusuf Turani, who also heads the East Turkistan National Freedom Center. A constitution in Turkish, Chinese, English, and Japanese versions calls for the formation of a parliamentary government. 
the Cold War. Zan says this was because Turkey, which until then was strategically important to the United States in the southern flank against communism, receded in value and had to rethink its place in the international system and develop relations with emerging countries. In Deng Hongying's view, this shift came about because of a more general disappointment with Western powers apart from US ties. This was due both to the European Union's reluctance to admit Turkey while seeking to prevent its getting too close to other Muslim countries and offering a "privileged partnership" (特殊伙伴关系, teshu huoban guanxi), as well as due to the deterioration in ties with Israel following the raid on a Turkish flotilla in May 2010. At the same time, Turkey gradually became aware of China's growing importance on the international scene. As Deng Hongying points out, there has been an "explosion" of bilateral commercial relations over the last decade; two-way trade crossed the billion-dollar mark in 2000 and rocketed to $\$ 12.6$ billion in 2008. China emerged as the third largest exporter to Turkey and its fourth largest trade partner. However, they're unbalanced; Zan underscores the lack of complementarity (Turkey exports hardly any energy resources) and the pressure from Chinese products on the Turkish market. In Zan's view, this imbalance, along with the two countries' lack of knowledge of each other (he notes the paltry study of Turkey in China), constitute a potential factor for conflict.

Zan Tao and Zhu Xiang stress that in Chinese eyes, Turkey remains the main external source of support for East-Turkistan movements. Zhu points to the Turkish government's rather vague role as regards the existence on its soil of a dozen or so East-Turkistan organisations, with their own resources and publication outlets. Zan sees a link between this laxness on the Turkish leadership's part and the ruling AKP or Justice and Development Party's international position of seeking rapprochement with Islamic countries. In Zan's view, the greatest implication for Turkey's Muslim neighbours, especially given its growing interventions in the Iranian and Palestinian issues, is a "Neo-Ottomanism" (新奥斯曼主义, xin aosiman zhuyi) in its foreign policy, translated into a growing weight in the regions that were part of its former empire. Zan and Zhu say that quite apart from trade matters, the Xinjiang issue is central to the development of Sino-Turkish relations. Zan says there is already some movement towards greater cooperation on this issue, given Turkey's growing awareness of China's power. He notes there have been statements to this effect, notably the signing on 14 February 2000 of a Sino-Turkish agreement to jointly combat transnational crime.

Despite these moves towards greater cooperation, Zan perceives a persistent anti-Chinese lobby in Turkey. According to this "radical line" (强硬派, qiangying pai) representing economic nationalism (经济民族主义, jingji minzu zhuyi), Turkey would be a mere jumping-off point for China to get to the European Union. In this regard he draws attention to the imbalance in bilateral trade. Chinese warnings against Turkish interference in the Xinjiang issue seem misplaced in Turkey's eyes, as China has itself been intrusive in matters that concern its interests, a good example being its support to leftist groups in Turkey in the 1960s. It is in this context that Zan places the Turkish prime minister's criticism of the Chinese government over its handling of the events of July 2009 in Urumqi. However, he remains confident as to the future growth of Sino-Turkish relations: for some of the most "pragmatic" Turkish leaders, the country has its own internal problems, especially the Kurdish question, on which it needs China's backing in international forums. Moreover, Turkey would be seeking to expand cooperation in military technologies, especially with regard to guided missiles.

Zan's article tends to stress the flexibility of Turkey's stand. According to him, Ankara has yet to set out a clear and well-defined strategy regarding China. Zhu Xiang, for his part, perceives a chequered history of bilateral relations, times of friction alternating with coordination (摩擦一协调一摩擦, moca-xietiao-moca). This lack of stability in relations is reflected in the two sides' approaches to the question of Central Asia, where Zhu sees them wavering between coordination and competition (协调一竞争-协调, xietiaojingzheng-xietiao). He underlines the danger to Xinjiang's stability stemming from the Turkish strategy of accentuating the common cultural and ethnic origins with Central Asian peoples in order to get close to countries in the region. Zhu links this strategy to "two pans" - Pan-Islamism and PanTurkism (双泛, shuangfan). In general, Turkey certainly remains vague on the regional question, but in Zan Tao's view the tendency is towards collaboration in Central Asia. After the Cold War, Turkey's rising international stature offers new opportunities to countries in the region in terms of investments, energy export outlets, and so on. And now, given the increasing presence in the region of China, which regards Central Asia as a frontline in the battle against terrorism, separatism, and religious extremism, as well as a source of energy security, Turkey should be able to firm up its regional presence.

The formation of the SCO was a major step in China's ascent in the region. With China's growing weight, the Xinjiang issue is gaining importance regionally. Among Chinese analysts, the tendency is to hold up the SCO as a guarantor of Xinjiang's stability, Wei Chaoran's article being an example of this view. Consequently the Turks have to face up to a greater need to cooperate with China. Zan says that in order to meet China's "needs," Turkey could play a bridging role between the East and the West and in the cooperation against terrorism and for stability in Xinjiang. For China, this should lead Turkey towards cooperating with the SCO on security issues. It follows from this that Turkey must clarify its position on the Uyghur issue and ultimately work with China against the EastTurkistan movements, in Zan's view. Only thus can Turkey gain influence within the SCO and obtain China's support in other forums.

To sum up, Sino-Turkish relations are developing in the direction of increased strategic cooperation. In October 2010, Turkey was the last leg of Premier Wen Jiabao's European tour. After meeting the Turkish leader Recep Tayyip Erdogan, Wen announced the development of cooperation on strategic issues and stressed that bilateral ties were growing favourably. Apart from forging closer economic ties - and with the "three evil forces" in mind - it was resolved to maintain mutual support on issues of sovereignty and regional and national security. (9) In November 2010, Vice President Xi Jinping met Turkey's Foreign Minister Ahmet Davutoglu. The need for collaboration in the fight against terrorism and separatism was noted in the context of next year's $40^{\text {th }}$ anniversary of the establishment of SinoTurkish diplomatic relations. (10) Moreover, in October and November 2010, the two countries held a joint military drill; it was China's first such exercise with a NATO member. ${ }^{(11)}$ Thus Sino-Turkish relations are in a cooperation phase, far from the events of 2009. However, as Zan emphasises, the decade ahead will be a period for Turkey to build its strategic position with regard to China, and many parameters hinging on the evolution of China's might are not yet clear.

\section{Translated by N. Jayaram}

9. "Wen Jiabao's visit: China and Turkey establish strategic relations," Hong Kong Economic Journal, no. 9 October 2010.

10. Xu Song, "Xi Jinping meets Turkish foreign minister," Xinhua, 1 November 2010.

11. "China, Turkey Conduct Second Major Exercise," World Tribune, 12 November 2010, http://www.worldtribune.com/worldtribune/WTARC/2010/me_turkey1121_11_12.asp. 